\title{
Efficiency in the Pakistani Banking Industry: Empirical Evidence after the Structural Reform in the Late 1990s
}

\begin{abstract}
ATSUSHI IIMI
This article examines the change in technical (in)efficiency of the Pakistani banking industry after the structural reform started in the late 1990s. With international assistance, the Pakistani government has undertaken the restructuring and preparation for privatisation of national commercial and development banks, of which the main goal is the improvement of the efficiency in financial markets. Despite the small sample size, the estimated stochastic production frontier indicates that employees are statistically productive, but capital in terms of branch network is not productive. This is an example counter to the common view that in a less developed banking industry, employees are too often idle and are not productive at all. It is also shown that the efficiency performance of the structural adjustment programmes is in marked contrast among banks. Some banks are found to have improved their technical efficiency during the reform period, while the efficiency improvement of others was ambiguous.
\end{abstract}

\section{INTRODUCTION}

The productivity in the banking industry has been of research interest for industrial economists, because although the banking sector had traditionally been a regulated industry, it became more deregulated in the 1990s. Thus, by comparing the estimated productivity before and after the structural reform including deregulation and privatisation, it is possible to empirically examine the reform effects. This type of investigation into bank efficiency is important from the viewpoint of macroeconomics as well, since adequate development of financial sectors is essential for stabilising the macro-economy and accelerating economic growth.

Atsushi Iimi is an economist working for the International Monetary Fund, Washington, D. C.

Author's Note: I thank Harumi Ito and seminar participants at the Japan Bank for International Cooperation Institute (JBICI) for helpful comments. The paper has benefited from data provision by the State Bank of Pakistan. I am also grateful for many suggestions by the SBP staff and an anonymous referee. Any errors remaining are the responsibility of the author. The views expressed in this paper are those of the author and do not represent any official positions of the International Monetary Fund. 
There are many previous studies discussing the efficiency and economies of scale and scope in the banking industry. For example, Berger, Leusner, and Mingo (1997) investigate the branch efficiency of U.S. large commercial banks from 1989 to 1991 , by separately estimating frontier-flexible and translog cost functions for several years. Their evidence shows that banks are likely to over-branch twice as much as the possible cost-minimising level, and technical inefficiency, namely Xinefficiency, amounts to about 20 percent of their operation costs. Berger and Hannan (1998) also examine the U.S. bank efficiency, concluding that the efficiency cost (i.e., X-inefficiency) resulting from a lack of market discipline is much larger than the deadweight welfare loss due to misallocation by monopoly power. ${ }^{1}$

Battese, Heshmati, and Hjalmarsson (1998) examine the efficiency of labour utilisation in the Swedish banking industry, using the stochastic frontier analysis (SFA). Regressing the labour input on the outputs of financial services such as loans, guarantees, and deposits, and the quasi-fixed input such as branches, given one-sided stochastic inefficiency and idiosyncratic noise, it is found that technical inefficiency of the banks in their use of labour is on average 12 percent above the stochastic frontier. Further, the technical inefficiency increased immediately after the reform in the banking industry in the mid-1980s; it has decreased due to the reform effect since 1991.

Adams, Berger and Sickles (1999) perform a stochastic panel distance frontier estimation, using the data of over 2500 U.S. banks over 10 years. The estimation of the Cobb-Douglas production functions indicates that technical efficiency scores normalised by the most efficient bank are quite small and range from 53.5 percent to 54.3 percent.

In this paper, I examine the change in technical (in)efficiency of the Pakistani banking industry, where the government has undertaken the restructuring and preparation for privatisation of nationalised commercial banks (NCBs) and development finance institutions (DFIs) since the late 1990s. Historically, the banking industry in Pakistan has been one of the most inefficient sectors due to religious and political reasons. In the Islamic banking system, the exaction of nonperforming loans (NPLs) may be difficult. Moreover, the Pakistani government has owned many public enterprises and large agriculture-based manufacturers, which are traditionally short of funds for new investment, operation, and maintenance. Thus, the government's instruction to finance such state-owned enterprises (SOEs) tended to be politically justifiable for securing the basic life of the public, and it seems to have been irresistible for the NCBs and DFIs.

As a result of such discretionary governmental intervention, rather than market competition, the Pakistani banking industry has accumulated a considerable

\footnotetext{
${ }^{1}$ Moreover, Berger, Saunders, Scalise, and Udell (1998) examine the bank efficiency change, focusing on the great number of merger and acquisition (M\&A) activities following the U.S. deregulation since the late 1970s. They estimate the impact of such bank M\&A on small business lending.
} 
amount of NPLs, which approximately amount to a half of the total credit. $^{2}$ The banking industry comes to play only a minor role in financial intermediation services. Even innovative business firms cannot have the access to bank finance, and no consumers are willing to make a deposit to such inefficient banks.

This inefficient financial system in Pakistan may be a crucial restriction on its economic growth. As Khan and Senhadji (2000) summarise previous empirical studies, there is a statistically significant relationship between economic growth and financial development. Using two macro-variables, GDP per capita as a proxy of economic growth and the ratio of domestic credit to GDP as a common indicator for financial depth, the relationship in major Asian developing countries is illustrated in Figure 1. It implies that the Pakistani low economic growth is related to (but not necessarily caused by) its immature financial system.

As to the relationship between economic growth and financial development, there is no clear historical trend in Pakistan. Figures 2 and 3 show per capita GDP in US dollar and the ratio of domestic credit to GDP. This may be caused by a measurement error that the domestic credit includes non-performing loans.

Given these situations, the Pakistani government started the macro-economic and financial sector restructuring programme under guidance of the International Monetary Fund (IMF) in 1996. The World Bank and the Japanese government also co-financed the banking sector adjustment loan (BSAL) to support this Pakistani government effort, of which the main goal is to improve the efficiency of financial institutions through separating ownership and management and strengthening the banks' accountability and the central bank's monitoring. It was expected that the more efficient financial system would lead to mobilisation of human resources in the banking industry, efficient allocation of domestic capital resources, and improvement in the access of the poor people to financial services. All these effects are conducive to stable economic growth and poverty reduction.

The first phase of the programme in 1997-1998 mainly consisted of (i) preventing a further increase of bad loans, (ii) recovery of NPLs through the "Incentive Scheme," invented by the State Bank of Pakistan (SBP), (iii) retrenchment of surplus staff through the "Golden Handshake Scheme" and closure of over-extended branches, (iv) preparation for privatising three NCBs and two DFIs, (v) introduction of international accounting standards and strengthening prudential regulation, and (vi) establishment of banking courts for enhancement of the solution of disputes related to NPLs through legal procedures.

Furthermore, the World Bank continued to support this structural adjustment in the banking sector and approved the second phase credit in October 2001. The second phase programme included (i) restructuring of the cost structure, (ii) complete privatisation of partially privatised banks, (iii) liberalisation of bank

\footnotetext{
${ }^{2}$ In the sample of the five major state-owned banks from 1997 to 2001 , the ratio of nonperforming loans ranges from 16.7 percent to 87.8 percent.
} 
Fig. 1. Financial Depth and GDP per Capita.

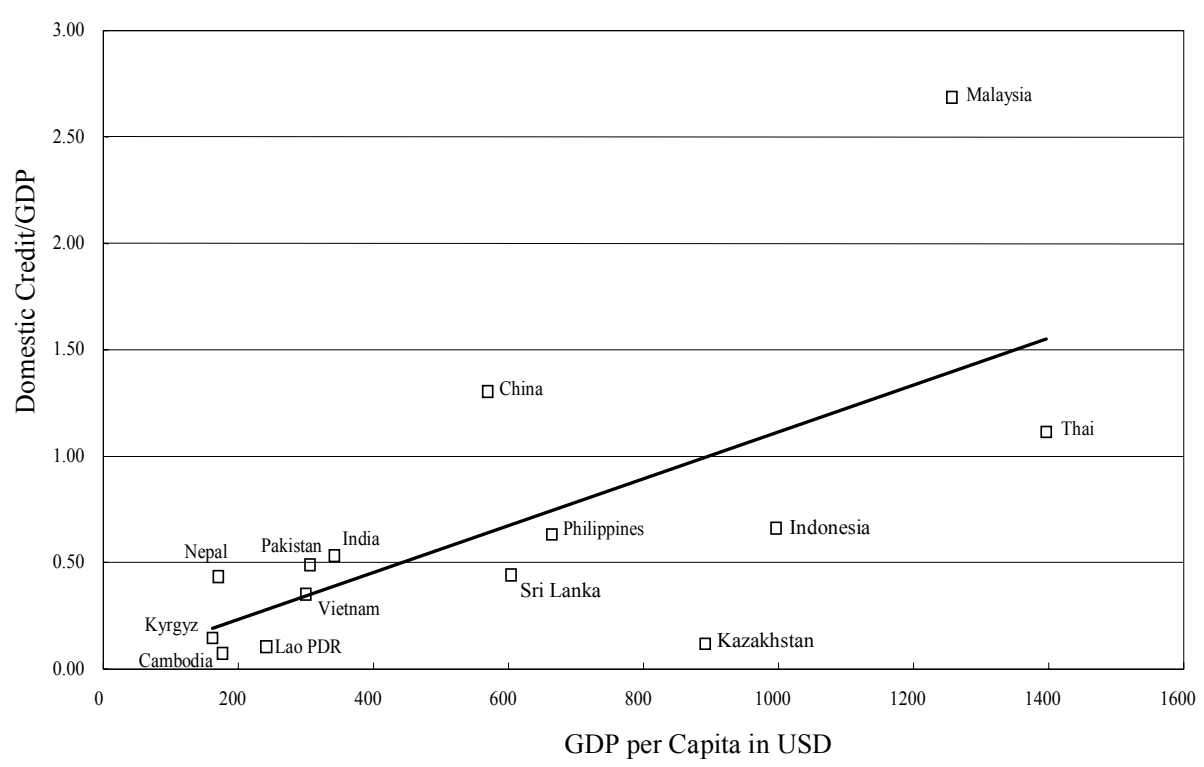

Fig. 2. Time Trend of Financial Depth and Economic Growth in Pakistan.

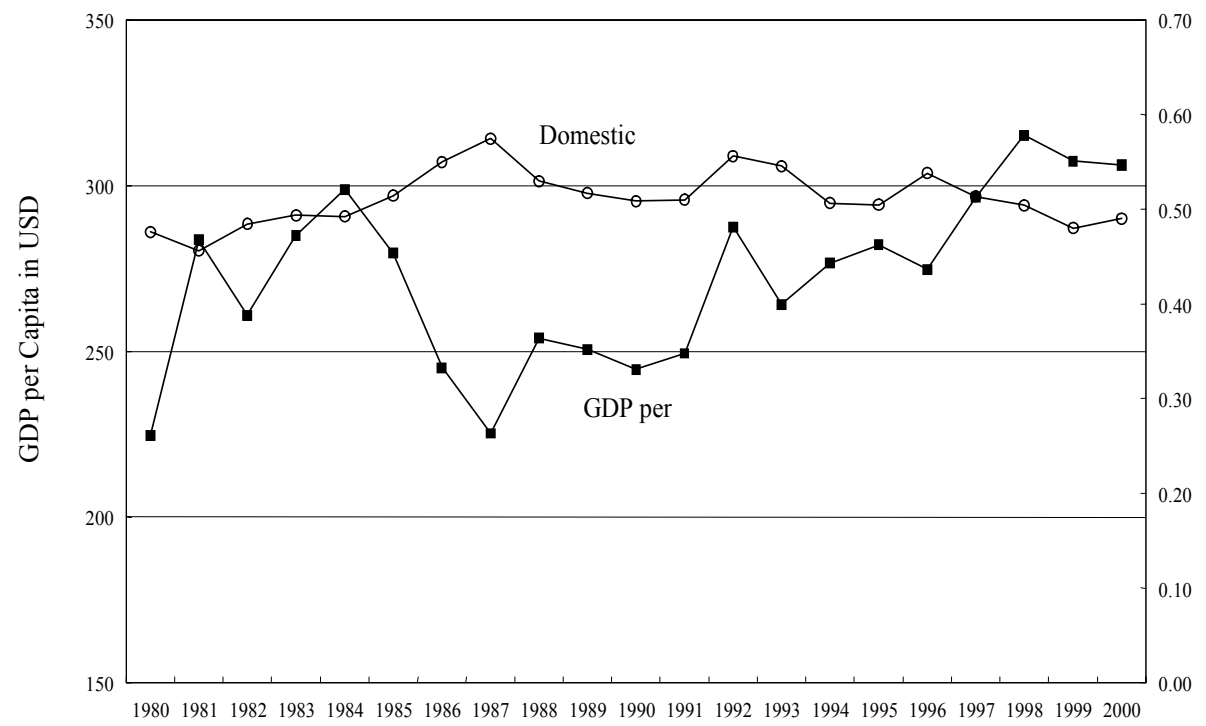


Fig. 3. Cycle of Economic Growth and Financial Depth.

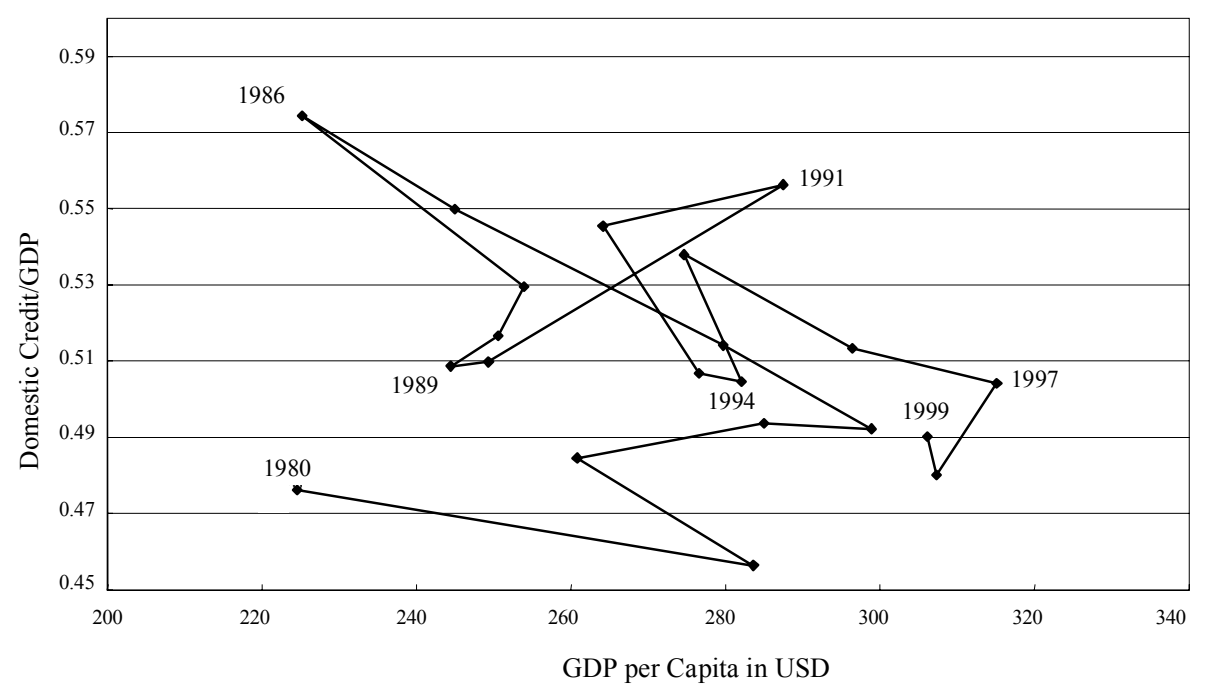

branching policy, (iv) facilitation of loan collateral foreclosure to reduce the default cost, (v) reform of the National Savings Schemes (NSS) to integrate the financial market, (vi) discontinuance of the mandatory placement of foreign currency deposits, and (vii) strengthening the central bank to play a more effective role as a regulator of the banking sector. ${ }^{3}$

Thus, the examination of the recent efficiency improvement in the Pakistani banking industry is directly related to the evaluation of the structural adjustment programmes. Recall that the effect of the structural adjustment in the late 1990s on financial development and economic growth is difficult to capture on the macroeconomic level. (See Figures 2 and 3.) Instead, in this paper, using the microdata of loans, labour and branch network, I examine the effectiveness of the programmes by estimating a stochastic production frontier of the banking industry over the reform period: 1997 to 2000. Although the number of observations is limited, yet it will be shown that some NCBs are continuously improving technical efficiency, while others are not.

This paper is organised as follows. In Section 2, I describe the data and discuss the definitions of input and output variables of banks. In Section 3, I present an econometric specification based on the standard SFA. In Section 4, I show the estimation results and discuss some implications and potential issues.

${ }^{3}$ For the details of these programmes, see Press Release, March 20, 1998, published by the Overseas Economic Cooperation Fund, Japan (currently Japan Bank of International Cooperation), and News Release No. 98/1563SAS by the World Bank. Also see News Release No. 2002/113/SAS for the World Bank's second phase assistance. 


\section{DATA AND DEFINITION OF INPUT AND OUTPUT}

I use micro-data on input and output, over the period December 1997 to March 2001, of five major state-owned banks: Habib Bank Limited (HBL), United Bank Limited (UBL), National Bank of Pakistan (NBP), Industrial Development Bank of Pakistan (IDBP), and National Development Finance Corporation (NDFC). ${ }^{4}$ These banks are dominating the domestic banking services in Pakistan. Since the main purpose of this paper is to examine the efficiency changes during and after the banking sector reform starting from around 1996, I restrict the current analysis to these five target banks and to the reform period.

Of course, this restriction makes for a small sample, but it is not always appropriate to increase the sample size, as pointed out by McCloskey and Ziliak (1996) and Kennedy (1998). Although almost any estimates can become significant if the sample size is sufficiently large, statistical significance does not imply economic significance (i.e., "too-large sample size problem"). In the current paper, this seems to matter. The banking sector reform in the late 1990s was a historic movement in Pakistan, and the current market structure is completely different from that before the mid-1990s. Therefore, I only use the latest data to keep the estimation results economically meaningful — and partly address the too-small sample problem through the bootstrap method.

Based on the duality theorem, I estimate a production frontier, instead of cost and profit functions [e.g., Diewert (1971)]. Estimating a production function is a useful approach to avoid two crucial problems: the input price endogeneity and the difficulty of measuring input prices, particularly the rental rates on capital. The second problem is typical and serious in studying the banking sector of developing countries, in which the labour and capital markets are not yet developed and are likely to be distorted by state intervention.

In choosing input and output variables, I rely on the production approach, where using labour and capital, banks are supposed to produce financial intermediation activities [Berger, Leusner and Mingo (1997)]. Banks are clearly multi-product firms. Accordingly, the variety of types of loans and deposits are used as outputs in the previous literature; there is no clear consensus about what assets or liabilities constitute outputs or inputs in the banking activities [Berger and Humphrey (1992); Berger and Hannan (1998); Adams, Berger and Sickles (1999)].

In this paper, I focus on lending operations. My focus is motivated by the view that in developing countries the most essential policy issue concerns the provision of sufficient lending money to growth sectors with an overriding priority to rapid industrialisation [Teranishi (1991)]. The mobilisation of domestic financial

${ }^{4}$ HBL, UBL, and NBP are grouped in the NCBs, and IDBP and NDFC belong to the DFIs. The State Bank of Pakistan mentions that the DFIs are not functioning on commercial basis but playing specially assigned roles, such as financing priority sectors. Thus, as I shall mention in the econometric part, their production function might be different than that of the national commercial banks. 
resources of households is also necessary but of secondary importance on the low levels of economic development, since surplus financial resources per se are relatively limited.

Further, often the developing countries have other systems playing a major role in deposit mobilisation. In Pakistan, in fact, the National Saving Schemes (NSS) have been used as an instrument of collecting financial savings; while the flows of deposits of scheduled banks collected only 6.4 percent of GDP in 1991, 4.6 percent in 1997, and 0.9 percent in 2000, the flows of the NSS as percent of GDP amounted to 4.2 percent, 11.8 percent, and 13.8 percent, respectively. ${ }^{5}$ Although it has been tried to mitigate the distortion of the NSS by a series of financial reforms, the profit rates of the NSS are still more attractive to depositors. This phenomenon may reflect the fact that the trustworthiness of banks is not enough to collect the saving money from the public at the earlier stage of financial development.

Another reason for choosing a simple production function with a single output is that the Pakistani financial sectors have started taking off. The monetary sophistication is not yet required so much; the total amount of loans can be considered as a primary output measurement of banks. Therefore, I only treat performing loans, defined by the total credit minus NPLs, as an output of the banking sector. ${ }^{6}$ It is clear that the total credit amount is not appropriate, because it may include non-performing loans. This does really matter in the case of the Pakistani banking industry, where the ratio of NPLs reaches more than 50 percent of total credit. ${ }^{7}$ I avoid this type of measurement error by using performing loans rather than the total credit.

For producing performing loans, I consider labour and capital as two physical inputs. It is natural that the number of employees working for each bank is used as an input labour quantity. On the other hand, the quantity of input capital is difficult to measure. ${ }^{8}$ In this paper, the capital amount is measured by the number of branches for each bank. This capital proxy seems to be more adequate than other accounting measurements of capital, such as book values of tangible assets. While the book values of any capital categories are largely dependent on accounting treatments, the number of branches suitably represents the physical network size per banks that is actually required for providing loans.

${ }^{5}$ Source: State Bank of Pakistan (2002a).

${ }^{6}$ There are various alternative output and input variables. According to the State Bank of Pakistan, the main activity of employees in the branch network in rural areas is to mobilise deposits, and thus the deposit amount may be one of reasonable output measures. Furthermore, one may consider the amount of newly loaned money to be a better output, which may be approximated by differentials of total credit. However, during the structural adjustment period, the total credit is greatly influenced by loan recovery, rather than new loans. My data do not allow for reducing the number of observations by taking the differentials. Therefore, in this paper, I use the gross amount of performing loans, but not new credit, as an output.

${ }^{7}$ According to State Bank of Pakistan (2002b), the non-performing loan rates in 1997 were 59.0 percent for state-owned banks, 2.3 percent for private banks, and 3.1 percent for foreign banks. For all banks, this rate was 64.4 percent.

${ }^{8}$ See Berger and Hannan (1998). 
Table 1 presents the summary statistics of input and output variables. The mean performing loan is 48.2 billion Rupees (Rs). Individual banks on average employ about 11,000 workers and have about 900 branches. But these figures significantly differ from bank to bank, as indicated by their maximum and minimum values in the table. Labour ranges from 510 to 24,000; capital varies with the range between 14 and 1,700 .

Table 1

Summary Statistics

\begin{tabular}{clrrrr}
\hline Symbol & Definition & Mean & Std. Dev. & \multicolumn{1}{c}{ Min } & \multicolumn{1}{c}{ Max } \\
\hline Y & Performing Loans (Rs Mil.) & 48219.1 & 42141.6 & 2711.0 & 112604.0 \\
L & Employees & 11012.2 & 9040.6 & 510 & 23599 \\
K & Branches & 908.4 & 768.9 & 14 & 1748 \\
\hline
\end{tabular}

Note that performing loans are defined by the total credit minus the amount of non-performing loans.

\section{ECONOMETRICS}

Following Fan, Li, and Weersink (1996), I estimate a simple stochastic production frontier for banks, which is statistically sophisticated in the sense that it has the two-part-composed-error term: one-sided stochastic error and two-sided idiosyncratic error. That is, the stochastic frontier analysis (SFA) distinguishes a non-negative random variable associated with technical inefficiency representing the deviation from the efficient production frontier from a random variable generated by any statistical errors. Although my data take the form of a balanced panel, I do not use that characteristic in order to save the degree of freedom of the small sample but pool the time-variant observations. ${ }^{9}$

Letting the amount of performing loans be $Y$, and the two physical inputs (i.e., employees and branches) be $L$ and $K$, the production function can be written as:

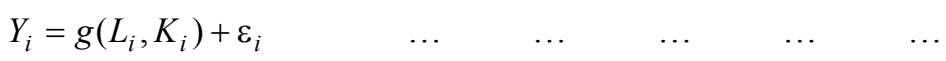

For the functional form, I employ a Cobb-Douglas specification and a flexible translog function, both of which are commonly used in empirical work:

$$
\ln Y_{i}=\beta_{0}+\beta_{L} \ln L_{i}+\beta_{K} \ln K_{i}+\varepsilon_{i} \quad \ldots \quad \ldots \quad \ldots \quad \ldots
$$

${ }^{9}$ For the details of the time-variant SFA, see Battese and Coelli (1992); Coelli (1996); Filippini (2001) and Battese, Rao, and Walujadi (2001). In particular, Battese and Coelli (1992) provide a complete form of the log-likelihood function to be maximised, and Coelli (1996) proposes a computer programme for that maximum likelihood estimation. 


$$
\begin{aligned}
& \ln Y_{i}=\beta_{0}+\beta_{L} \ln L_{i}+\beta_{K} \ln K_{i}+\frac{1}{2} \beta_{L L}\left(\ln L_{i}\right)^{2}+\beta_{L K} \ln L_{i} \ln K_{i} \\
& \begin{array}{lllllll} 
& +\frac{1}{2} \beta_{K K}\left(\ln K_{i}\right)^{2}+\varepsilon_{i} & \ldots & \ldots & \ldots & \ldots & \ldots
\end{array}
\end{aligned}
$$

I here impose the condition for symmetry, i.e., $\beta_{L K}=\beta_{K L}$. The error term is decomposed as follows:

$$
\begin{array}{lllllll}
\varepsilon_{i}=v_{i}-u_{i} & \ldots & \ldots & \ldots & \ldots & \ldots & \ldots
\end{array}
$$

where $u_{i}$, which indicates a non-negative technical inefficiency, is assumed to be independently and identically distributed (i.i.d.) according to a half-normal distribution $\left|N\left(0, \sigma_{u}\right)\right|$, and $v_{i}$ is i.i.d. according to a standard normal distribution $N\left(0, \sigma_{v}\right)$, representing a statistical error.

As Weinstein (1964) proves, the probability density function of the sum of normal and truncated normal distributions is:

$$
f(\varepsilon)=\frac{2}{\sigma} \phi\left(\frac{\varepsilon}{\sigma}\right)\left[1-\Phi\left(\frac{\lambda \varepsilon}{\sigma}\right)\right] \quad \text { for }-\infty<\varepsilon<\infty \quad \ldots \quad \ldots
$$

where $\phi(\cdot)$ and $\Phi(\cdot)$ are the normal probability and cumulative density functions respectively. Note that in Equation (5), I re-parameterise $\sigma^{2}=\sigma_{u}{ }^{2}+\sigma_{v}{ }^{2}$ and $\lambda=\sigma_{u} / \sigma_{v}$, as usual. Recall that $\varepsilon=\ln Y-g(\ln L, \ln K ; \beta)$.

Then, the log-likelihood function can be written as follows [Fan, Li and Weersink (1996)]:

$$
\ln l(\ln Y \mid \lambda, \sigma, \beta)=\frac{n}{2} \ln \left(\frac{2}{\pi}\right)-n \ln \sigma+\sum_{i=1}^{n} \ln \left[1-\Phi\left(\frac{\lambda \varepsilon_{i}}{\sigma}\right)\right]-\frac{1}{2 \sigma^{2}} \sum_{i=1}^{n} \varepsilon_{i}{ }^{2} \ldots
$$

where $n$ is the number of pooled observations. The individual estimates of technical inefficiency can be obtained by the conditional expectation of $u_{i}$ given $\varepsilon_{i}$ :

$$
E\left[u_{i} \mid \varepsilon_{i}\right]=\frac{\sigma \lambda}{1+\lambda^{2}}\left[\frac{\phi\left(\lambda \varepsilon_{i} / \sigma\right)}{1-\Phi\left(\lambda \varepsilon_{i} / \sigma\right)}-\frac{\lambda \varepsilon_{i}}{\sigma}\right] \quad \ldots \quad \ldots \quad \ldots
$$

The technical efficiency $(T E)$ is defined as minus the exponential of the conditional inefficiency:

$$
T E_{i}=E\left[\exp \left(-u_{i}\right) \mid \varepsilon_{i}\right] \quad \ldots \quad \ldots \quad \ldots \quad \ldots \quad \ldots
$$




\section{ESTIMATION RESULTS}

For purposes of reference, I perform the standard ordinary least squares (OLS) estimation as well as the SFA. Table 2 shows both estimates. First of all, according to the Ramsey RESET test, the Cobb-Douglas specification given in Equation (2) is not acceptable; the hypothesis that there is no omitted variable can be rejected in the first column OLS model. On the other hand, the same hypothesis cannot be rejected in the case of Column 3, which follows the flexible translog specification given in Equation (3). Therefore, I can concentrate on analysing the estimation results of the translog production function.

In Table 3, I present a main finding of this paper, which is about the elasticity of output with respect to each production factor, evaluated at the mean values. It is clear that labour is productive in a concave fashion, but capital may or may not be productive. Based on the SFA coefficients, a 1 percent increase in employees results in a 0.8 percent increase in performing loans. Although a serious concern in the Pakistani banking industry is that employees are utilised in excess and are idle, the evidence does not indicate such a case. This evidence is plausible, when taking into consideration the fact that the Pakistani banking industry remains at the initial stage of financial development and continues to be a labour-intensive industry.

Table 2

\begin{tabular}{|c|c|c|c|c|}
\hline & $\overline{\text { OLS }}$ & SFA & OLS & SFA \\
\hline $\operatorname{lnL}$ & $\begin{array}{c}0.33 \\
(0.62)\end{array}$ & $\begin{array}{l}-0.13 \\
(0.0001)\end{array}$ & $\begin{array}{c}33.47 \\
(28.15)\end{array}$ & $\begin{array}{l}31.59 \\
(1.29)\end{array}$ \\
\hline $\ln K$ & $\begin{array}{c}0.23 \\
(0.49)\end{array}$ & $\begin{array}{l}0.59 \\
(0.0001)\end{array}$ & $\begin{array}{l}-26.32 \\
(17.86)\end{array}$ & $\begin{array}{r}-22.99 \\
(1.94)\end{array}$ \\
\hline$(1 / 2) \operatorname{lnL} \operatorname{lnL}$ & & & $\begin{array}{l}-7.87 \\
(6.17)\end{array}$ & $\begin{array}{c}-7.23 \\
(0.41)\end{array}$ \\
\hline$(1 / 2) \ln K \ln K$ & & & $\begin{array}{l}-4.60 \\
(3.65)\end{array}$ & $\begin{array}{l}-3.93 \\
(0.15)\end{array}$ \\
\hline $\ln L \ln K$ & & & $\begin{array}{c}6.10 \\
(4.43)\end{array}$ & $\begin{array}{c}5.34 \\
(0.35)\end{array}$ \\
\hline Cons & $\begin{array}{c}6.21 \\
(2.46) \\
\end{array}$ & 8.63 & $\begin{array}{c}-60.86 \\
(68.45) \\
\end{array}$ & -60.13 \\
\hline Lambda & & $\begin{array}{l}3.7 \mathrm{E}+06 \\
(0.119)\end{array}$ & & $\begin{array}{l}1.5 \mathrm{E}+04 \\
(0.083)\end{array}$ \\
\hline Sigma Square & & $\begin{array}{c}0.705 \\
(0.199)\end{array}$ & & $\begin{array}{c}0.348 \\
(0.098)\end{array}$ \\
\hline Obs. & 25 & 25 & 25 & 25 \\
\hline Log Likelihood & & -13.765 & & -4.935 \\
\hline $\begin{array}{l}\text { R-squared } \\
\text { RESET Test }\end{array}$ & 0.735 & & 0.872 & \\
\hline F-statistics & 5.98 & & 0.29 & \\
\hline
\end{tabular}

The dependent variable is the logarithm of the performing loan amount. Note that the (White heteroscedasticity) standard errors are shown in parentheses (for OLS estimation). 
Table 3

Estimated Product Elasticities

\begin{tabular}{lcc}
\hline & \multicolumn{2}{c}{ Translog } \\
\cline { 2 - 3 } & OLS & SFA \\
\hline$\partial \mathrm{Y} L$ & 1.645 & $0.819^{* * *}$ \\
$\mathrm{~L}$ & $(1.153)$ & $(0.165)$ \\
$\frac{\mathrm{Y}}{\partial \mathrm{K}} \underline{\mathrm{K}}$ & -0.868 & -0.191 \\
$\mathrm{y}$ & $(1.169)$ & $(0.169)$ \\
\hline
\end{tabular}

***: 1 percent significance level.

The elasticity of output with respect to each production factor with the mean evaluation is indicated. The standard errors are shown in parentheses.

It is noteworthy that there exists inefficient labour use on the bank-level, even though labour is generally productive. For example, the output elasticities associated with labour are negative for HBL and others, as shown in Table $4 .{ }^{10}$

Contrary to this, the effect of extending branch network is not different from zero and may be even negative. This means that banks are severely suffering from over-branching and they should restructure their over-extended branches more aggressively, particularly in the rural areas. ${ }^{11}$ In other words, the targeted banks have mainly responded to the structural adjustment programmes by staff retrenchment (through the Golden Handshake Scheme), rather than branch closing.

Table 4

Estimated Bank-level Product Elasticities to Labour

\begin{tabular}{lccccc}
\hline$(\partial \mathrm{Y} / \partial \mathrm{L})(\mathrm{L} / \mathrm{Y})$ & $\mathrm{HBL}$ & $\mathrm{UBL}$ & $\mathrm{NBP}$ & $\mathrm{IDBP}$ & $\mathrm{NDFC}$ \\
\hline $1997-12$ & 70.957 & 0.918 & -0.318 & -3.364 & 3.909 \\
& $(3.897)$ & $(0.073)$ & $(0.148$ & $(0.556)$ & $(0.091)$ \\
$1998-06$ & -1005 & 0.179 & 0.473 & 2.053 & 3.536 \\
& $(0.177)$ & $(0.118)$ & $(0.102)$ & $(0.234)$ & $(0.112)$ \\
$1998-12$ & -0.991 & -4.711 & 0.483 & 2.095 & 3.961 \\
& $(0.178)$ & $(0.453)$ & $(0.090)$ & $(0.231)$ & $(0.088)$ \\
$1999-06$ & -1.042 & 1.421 & 0.751 & 2.095 & 3.961 \\
& $(0.181)$ & $(0.049)$ & $(0.086)$ & $(0.231)$ & $(0.088)$ \\
$2000-03$ & -1.103 & 1.318 & 0.915 & 2.222 & 3.909 \\
& $(0.185)$ & $(0.057)$ & $(0.077)$ & $(0.224)$ & $(0.091)$ \\
\hline
\end{tabular}

The standard errors are shown in parentheses.

\footnotetext{
${ }^{10}$ The ratio of overuse of labour in the Swedish banking industry, calculated by Battese, Heshmati, and Hjalmarsson (1998), is on average 12 percent.

${ }^{11}$ This finding of banks' over-branching does not seem to be unique for Pakistan but is common for many countries [e.g., Berger, Leusner, and Mingo (1997)].
} 
In Table 5, I calculate bank-specific technical efficiency given in Equation (8) and depict the estimated efficiency in Figure 4. Significantly, the effects of the structural adjustment programmes (starting from 1997) on the banking efficiency vary across banks. It is shown that Habib Bank Limited (HBL) and National Bank of Pakistan (NBP) were improving the technical efficiency over the period, while the technical inefficiency of the other banks tends to be increasing or fluctuating. The efficiency of Industrial Development Bank of Pakistan (IDBP) was relatively high

Table 5

\begin{tabular}{lcccccc}
\multicolumn{7}{c}{ Estimated Technical Efficiency } \\
\hline $1997-12$ & HBL & UBL & NBP & IDBP & NDFC & Average \\
$1998-06$ & 0.7565 & 0.3978 & 0.5505 & 0.9998 & 0.9999 & 0.7409 \\
$1998-12$ & 0.7829 & 0.1869 & 0.8829 & 0.8675 & 0.9390 & 0.7236 \\
$1999-06$ & 0.9373 & 0.3037 & 0.9999 & 0.9090 & 0.9300 & 0.8160 \\
$2000-03$ & 0.9998 & 0.3802 & 0.9464 & 0.8816 & 0.2965 & 0.7009 \\
\hline Average & 0.8436 & 0.4206 & 0.8563 & 0.9190 & 0.7328 & 0.7545 \\
\hline
\end{tabular}

Fig. 4. Estimated Technical Efficiency.

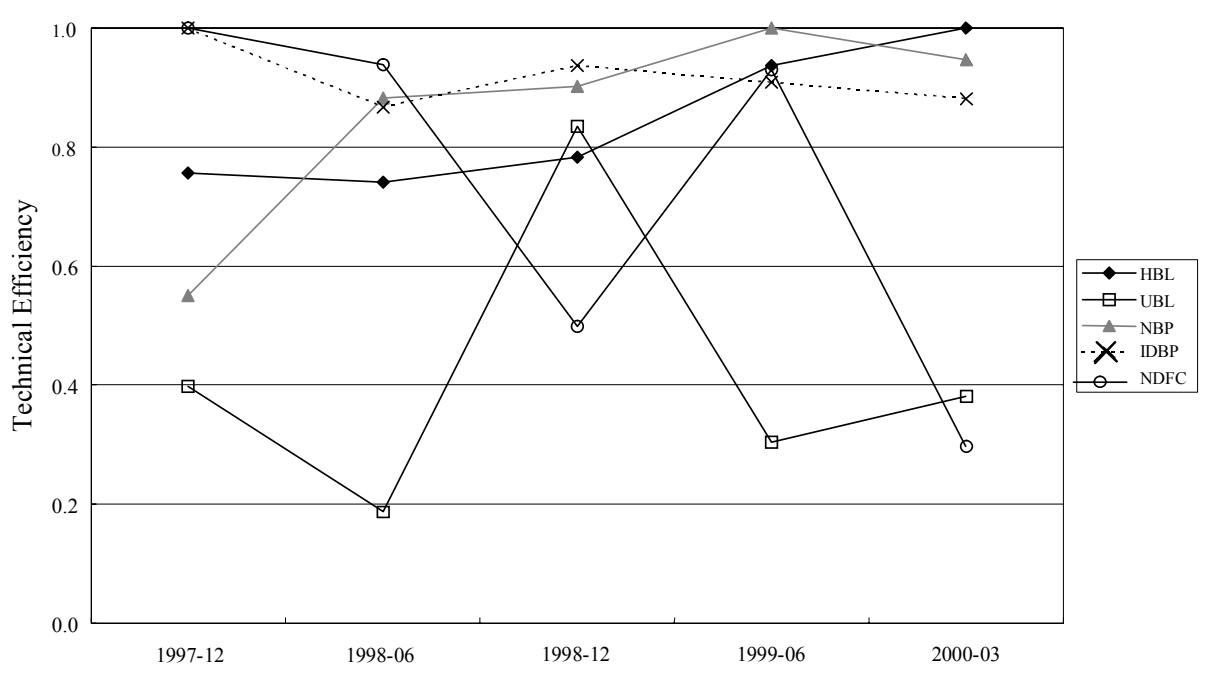


but slightly declining. The United Bank Limited (UBL) and National Development Finance Corporation (NDFC) in general deteriorated in efficiency with a large fluctuation. The reason for some predictions significantly departing from the estimated frontier is that although non-performing loans may pop up at the time of re-evaluating bank assets, the increase or decrease in labour and capital is gradual. The average efficiency for IDBP is the highest, followed by HBL and NBP. The efficiency level for UBL is the lowest and is not half that of the best-practising bank, IDBP. This large efficiency difference is not exaggerated and is consistent with the previous work, e.g., Adams, Berger, and Sickles (1999). ${ }^{12}$ At the latest reference point, HBL is the most efficient bank.

The differential in technical efficiencies ranges from 43.9 percent to 75.2 percent and seems to have been increasing after 1999, implying that there appear to be more striking differences between banks that are undergoing internal restructuring and banks that are failing to do so. The dichotomy is caused by the difference in the initial conditions of individual banks and their effort levels in restructuring their internal organisations during the reform period.

On the above estimation results, there are several limitations. First of all, the sample size is small, and thus the results may not be efficient. This results from data non-availability; more data would lessen the estimation inefficiency. With regard to this point, the bootstrap estimates shown in Table 6 may provide a part of the answer; although the standard errors are large due to the nature of the SFA locally maximising the likelihood function, the coefficients are similar to the baseline estimates in Table 2.

Secondly, there are alternative inputs and outputs of the banking industry, as I have mentioned. In addition, they may vary across banks. Related to this point, in the above argument, I implicitly assume a single common production function for all banks. ${ }^{13}$ However, the production frontier may be different among banks, since banks usually differentiate their financial services and provide vertically different services to different types of firms and consumers. Some finance large manufacturers at a low interest rate, while others provide only small business loans at a relatively high interest rate. If this is the case, the labour (or branch) productivity may take different forms bank by bank. Nevertheless, the five banks sampled in the current paper seem to engage in similar financial services.

\footnotetext{
${ }^{12}$ Their estimation indicates that the relative technical efficiency in the U.S. banking industry is about 53 percent, relative to the best-efficient production experience.

${ }^{13}$ The State Bank of Pakistan mentioned that during the period, the production function might be significantly shifted by political shocks, e.g., the detonation of a nuclear device in May 1998 resulting in the frozen foreign currency deposits, and the military takeover in October 1999. Moreover, the estimation results should be adjusted by seasonal factors and other institutional schemes, such as the export finance scheme. Nevertheless, the given data is not sufficient to account for these issues.
} 
Table 6

\section{Bootstrap Estimation}

\begin{tabular}{lcc}
\hline & OLS & SFA \\
\hline $\ln \mathrm{L}$ & 27.19 & 51.43 \\
& $(66.50)$ & $(63.32)$ \\
$\ln \mathrm{K}$ & -22.01 & -37.84 \\
& $(53.63)$ & $(50.78)$ \\
$(1 / 2) \ln \mathrm{lnL}$ & -6.38 & -12.16 \\
& $(17.83)$ & $(16.80)$ \\
$(1 / 2) \ln \mathrm{ln} \ln$ & -3.61 & -7.33 \\
& $(12.68)$ & $(11.81)$ \\
$\ln \mathrm{lnK}$ & 4.96 & 9.30 \\
& $(14.90)$ & $(13.96)$ \\
Cons & -46.54 & -102.30 \\
& $(132.01)$ & $(127.14)$ \\
\hline Obs. & 25 & 25 \\
Repetition & 1000 & 1000 \\
\hline The dependent variable is the logarithm of the performing loan amount. The standard errors are shown in \\
parentheses.
\end{tabular}

Another justification in economics against the single production frontier assumption is that a hull frontier in the long-run exists, even if firms' adopted technologies are heterogeneous.

Finally, the most serious limitation of this paper is this: all the estimation results are relative values within the Pakistani state-owned banking industry. If all the banks are equally inefficient, the measured efficiency might be over-estimated. Thus, the estimation results should be interpreted more carefully; some Pakistani banks are more efficient than others, and all Pakistani banks might operate far below the standard production frontier in the world.

\section{CONCLUSION}

In this paper, I examine the change in technical (in)efficiency of the Pakistani banking industry, by estimating a stochastic production frontier. As the banking industry is one of the most inefficient sectors in Pakistan, the government has undertaken the restructuring and preparation for privatisation of the major stateowned banks since the late 1990s. The main goal is to improve the efficiency in financial markets through separating ownership and management, and to strengthen the accountability and monitoring mechanisms. Since it is well-known that financial development is positively correlated to economic growth, the international and bilateral organisations have supported the Pakistani government's reform efforts by providing the structural adjustment programme loans. 
By using the stochastic frontier analysis, I found that employees are significantly productive in a statistical sense, but banks suffer from over-branching. Thus, a serious concern that the banks are overstaffed and the employees are too often idle, in the Pakistani banking industry may not be well-supported by the evidence. However, banks should step up branch retrenchment further. This positive productivity of labour input in part reflects the fact that the Pakistani banking industry remains quite labour-intensive.

Based on the SFA estimates, it is also shown that HBL and NBP are improving the technical efficiency over the reform period, while the technical efficiency of UBL and NDFC is ambiguous. Thus, the efficiency performance of the former banks, after the structural adjustment programmes, is in marked contrast to that of the latter; some banks are responding to the structural reform, others not.

A main policy implication to be derived from the estimation results is that the Pakistani government encourage relatively inefficient banks to engage more aggressively in restructuring their internal organisations and establishing an efficient corporate structure. The possible way to efficient production, of which the effectiveness is directly uncovered in this paper, is the retrenchment of staff and closing down of extra branches, as intended by the programmes. Branch retrenchment, particularly, must have a crucial effect. In addition, there exist other ways for banks to improve efficiency; they can provide job training for their employees to become more skilled in terms of financial knowledge. Banks are able to replace unskilled labour with information/technological systems, and skilled labour with advanced knowledge for operating them. They can also build up more effective internal incentive schemes for employees to improve their morale and encourage them to work harder, even without managerial monitoring.

Since the existing over-employment of the Pakistani state-owned banks partly results from the governmental employment measures, the strategies aiming at enhancing the existing labour abilities might be more effective in banks' progressive restructuring, rather than the simple retrenchment of staff. Of course, since new internal training and incentive systems are difficult to introduce, one key reform is the replacement of top management by outsiders with sufficient experience and advanced knowledge, which constitutes the World Bank-assisted programmes.

One remaining important issue is that the evidence in this paper does not show that such measures imply the absolute efficiency improvement in the Pakistani banking industry. It is still possible that all the Pakistani banks would be operating inefficiently, compared to the average of the international efficiency level. Thus, the Pakistani government might have to continue restructuring the entire banking industry, and engage in making overall financial development conducive to stable economic growth and poverty reduction. 
To follow this point, richer data in future investigation would allow for estimating a production frontier more efficiently, providing for more specific policy implications. If detailed data of the financial and managerial structures, particularly including foreign banks in Pakistan, are available, this would show whether domestic state-owned banks operated less efficiently than the international standard level, and if so, what caused domestic bank inefficiency. Then, more concrete restructuring plans could be provided for the Pakistani banks.

\section{REFERENCES}

Adams, R., A. Berger, and R. Sickles (1999) Semi-parametric Approaches to Stochastic Panel Frontiers, with Applications in the Banking Industry. Journal of Business and Economic Statistics 17:3, 349-358.

Battese, G. E., and T. J. Coelli (1992) Frontier Production Functions, Technical Efficiency, and Panel Data, with Application to Paddy Farmers in India. The Journal of Productivity Analysis 3, 153-169.

Battese, G. E., A. Heshmati, and L. Hjalmarsson (1998) Efficiency of Labour Use in the Swedish Banking Industry: A Stochastic Frontier Approach. Department of Economics, University of New England. (CEPA Working Paper No. 6/98.)

Battese, G. E., D. S. Rao, and D. Walujadi (2001) Technical Efficiency and Productivity Potential of Garment Firms in Different Regions in Indonesia: A Stochastic Frontier Analysis Using a Time-varying Inefficient Model and a Metaproduction Frontier. Department of Economics, University of New England. (CEPA Working Paper No. 7/2001.)

Berger, A., and D. Humphrey (1992) Measurement and Efficiency Issues in Commercial Banking. In Z. Griliches (ed.) Output Measurement in the Service Sectors. Chicago and London: The University of Chicago Press. pp. 245-300.

Berger, A., J. Leusner, and J. Mingo (1997) The Efficiency of Bank Branches. Journal of Monetary Economics 40:1, 141-162.

Berger, A., A. Saunders, J. Scalise, and G. Udell (1998) The Effects of Bank Mergers and Acquisitions on Small Business Lending. Journal of Financial Economics 50:2, 187-229.

Berger, A., and T. Hannan (1998) The Efficiency Cost of Market Power in the Banking Industry: A Test of the "Quiet Life" and Related Hypotheses. Review of Economics and Statistics 80:3, 454-465.

Coelli, T. J. (1996) A Guide to FRONTIER version 4.1: A Computer Programme for Stochastic Frontier Production and Cost Function Estimation. (Mimeographed.)

Diewert, W. E. (1971) An Application of the Shephard Duality Theorem: A Generalised Leontief Production Function. The Journal of Political Economy 79:3, 481-507. 
Fan, Y., Q. Li, and A. Weersink (1996) Semi-parametric Estimation of Stochastic Production Frontier Models. Journal of Business and Economic Statistics 14:4, 460-468.

Filippini, M. (2001) Economies of Scale in the Swiss Nursing Home Industry. Applied Economics Letters 8:1, 43-46.

Kennedy, P. (1998) A Guide to Econometrics. 4th Edition. Cambridge, Massachusetts: The MIT Press.

Khan, M., and A. Senhadji (2000) Financial Development and Economic Growth: An Overview. International Monetary Fund, Washington, D. C. (IMF Working Paper No. WP/00/209.)

McCloskey, D., and S. Ziliak (1996) The Standard Error of Regressions. Journal of Economic Literature 34:1, 97-114.

State Bank of Pakistan (2002a) Annual Report 2001-2002. State Bank of Pakistan. Karachi.

State Bank of Pakistan (2002b) Pakistan: Financial Sector Assessment 1990-2000. State Bank of Pakistan, Karachi.

Teranishi, J. (1991) Industrialisation and Financial Systems. In Japanese (Kogyoka to Kinyuu Shisutemu.) Tokyo: Toyokeizaishinpousha.

Weinstein, M. (1964) The Sum of Values from a Normal and a Truncated Normal Distribution. Technometrics 6, 104-105. 